\title{
Obstructive jaundice induces early depression of mitochondrial respiration in rat hepatocytes ${ }^{1}$
}

\author{
A icterícia obstrutiva induz depressão precoce da respiração mitocondrial \\ em hepatócitos de ratos
}

\author{
Riad Naim Younes ${ }^{2}$, Renato Sergio Poggetti ${ }^{3}$, Belchor Fontes ${ }^{4}$, Mario Matsuo Itinoshe ${ }^{5}$ Vanda Mitie Yoshida ${ }^{6}$, \\ Maria Elisa A.Carvalho ${ }^{7}$, Dario Birolini ${ }^{8}$ \\ 1. Research performed at Laboratory of Medical Investigation (LIM-62) and Experimental Research Division (ERD) of the Heart Institute (HI), \\ University of Sao Paulo School of Medicine (USPSM), São Paulo, Brazil. \\ 2. PhD, Assistant Surgeon, Trauma Division, USPSM, São Paulo, Brazil. \\ 3. PhD, Associate Professor, USPSM, São Paulo, Brazil. \\ 4. PhD, Department of Surgery, USPSM, São Paulo, Brazil. \\ 5. Biologist, Researcher at the LIM-62,USPSM, São Paulo, Brazil. \\ 6. Pharmacist, Researcher at the ERD, HI, USPSM, São Paulo, Brazil. \\ 7. MD, Researcher at the ERD, HI, USPSM, São Paulo, Brazil. \\ 8. Full Professor of Surgery, Trauma Division, USPSM, São Paulo, Brazil.
}

\begin{abstract}
Introduction: Oxidative phosphorylation dysfunction of hepatocyte mitochondria is involved in the pathophysiology of organ dysfunction following obstructive jaundice (OJ). However the time period from biliary occlusion to the occurrence of the dysfunction has not been determined decisively. Purpose: To evaluate the early effects ( $1 \mathrm{~d}$ and $7 \mathrm{~d}$ ) of OJ on liver mitochondria respiratory function in rats. Methods: Male Wistar rats (200-250 g) were randomly divided into the following 3 groups: laparotomy plus OJ for $24 \mathrm{~h}$ (1d group) $(\mathrm{n}=10)$; laparotomy plus OJ for $7 \mathrm{~d}$ (7d group) $(\mathrm{n}=10)$; sham control procedure (CTR group) $(\mathrm{n}=12)$. At the end of OJ periods, total serum bilirubin level, hepatic enzyme activity levels (GOT, GTP, Gama-GT, ALP), mitochondrial respiration phases S3 and S4, as well as the respiratory control ratio (RC = S3/S4), and ADP consumption/oxygen consumption (ADP/O) ratio, were determined. Results: Total serum bilirubin, activity of most hepatic enzymes, and O2 consumption during basal (S4) respiration were increased in the 1d and 7d groups (ANOVA, $\mathrm{p}=0.05$ vs. CTR). After ADP addition, the $\mathrm{O}_{2}$ consumption rate (S3) in the $1 \mathrm{~d}$ group remained similar to the CTR rate (ANOVA $>$.05), while the RC rate was reduced (ANOVA, $p=0.001$ ) vs. CTR. The effects observed on mitochondrial respiration in the $1 \mathrm{~d}$ group were exacerbated in the $7 \mathrm{~d}$ group. Conclusion: These results indicate that OJ induces early (24 h) depression of liver mitochondria respiration, and thus may lead to early reduction in the production of high energy bonds.
\end{abstract}

Key words: Jaundice, Obstructive. Mitochondria, Liver. Oxidative Phosphorylation.

\section{RESUMO}

Introdução: A disfunção da fosforilação oxidativa das mitocôndrias do hepatócito está envolvida na fisiopatologia da disfunção orgânica subseqüente à icterícia obstrutiva (IO). Entretanto, a precocidade da ocorrência desta disfunção permanece obscura. Objetivo: Avaliar o efeito precoce da IO na função respiratória mitocondrial em ratos. Métodos: Ratos Wistar machos (200 a 250g) foram randomizados em 3 grupos que foram submetidos a laparotomia mais: IO por 24hs (grupo 1d)(n=10); IO por 7 dias (grupo 7d)(n=10; procedimento simulado (grupo CTR)(n=12). Ao final dos períodos de IO, foram determinados: bilirrubina sérica total, atividade de enzimas hepáticas (TGO, TGP, Gama-GT, FA), e as fases S3 e S4 da respiração mitocondrial, bem como o razão do controle respiratório (RC = S3/S4), e a razão entre consumo de ADP/consumo de oxigênio (ADP/O). Resultados: Observou-se significativo aumento de bilirrubina sérica total, enzimas hepáticas, e consumo de O2 durante a respiração basal (S4) no grupo de IO por 24hs (ANOVA, p=0.009). Após adição de ADP, a taxa de consumo de O2 (S3) não diminuiu significativamente no grupo de IO, comparado com o CTR (ANOVA, p>0.05); entretanto, a razão do controle respiratório (RC) foi significativamente mais baixa comparada com o CTR (ANOVA, p=0.001). Os efeitos observados na respiração mitocondrial no grupo do dia 1d estavam exacerbados no grupo 7d. Conclusão: Estes resultados indicam que a icterícia obstrutiva induz depressão precoce (24hs) da respiração mitocondrial, e pode assim levar à redução da produção de ligações de alta energia.

Descritores: Icterícia Obstrutiva. Mitocôndria Hepática. Fosforilação Oxidativa. 


\section{Introduction}

The high morbidity and mortality rates associated with the surgical treatment of patients with obstructive jaundice (OJ) have frequently been attributed to metabolic disorders, specifically disorders of the oxidation-reduction function of hepatocyte mitochondria., ${ }^{1,2}$ It was shown in rats in the 1960s, that elevated bilirubin levels were associated with altered oxidative phosphorylation of liver mitochondria. This phosphorylation disturbance was attributed to a possible affinity of bilirubin for lipid binding sites in the mitochondrial membrane. ${ }^{3}$ Mitochondria isolated from the hepatic parenchyma of jaundiced rats were found to exhibit greater dysfunction than mitochondria extracted from hepatocytes, implicating the involvement of extramitochondrial mediators in this dysfunction. ${ }^{4}$ Other potential factors for this mitochondrial dysfunction include biliary infection, ${ }^{5,6}$ degradation of mitochondrial phospholipids caused by the increased biliary salts in $\mathrm{OJ},{ }^{7}$ and the increased expression of uncoupling protein $2 .^{8}$ In the $1980 \mathrm{~s}$ it was observed that alterations in hepatocyte mitochondrial respiratory function in jaundiced rats were amplified with increased duration of biliary occlusion, ${ }^{9}$ such that ATP production was reduced by $25 \%$ in the first and second weeks, and by $42 \%$ in the third week after biliary occlusion. This progressive depression in ATP production was accompanied by an increase in the serum concentrations of liver enzymes (AST, ALT, GGT, ALP). ${ }^{10}$ Several independent research groups have reported evidence of mitochondrial dysfunction onset as early as $3 \mathrm{~d}$ after biliary occlusion. ${ }^{2,7,9,10,11}$ However, it has not yet been clearly established how early after biliary occlusion that this dysfunction first becomes detectable. The objective of the present study was to examine the effects of OJ on mitochondrial function as well as on serum bilirubin and liver enzyme levels in rats submitted to bile duct occlusion at a very early post-occlusion time point (24 h).

\section{Methods}

All procedures were performed in accordance with the norms of the Institution Ethical Committee for animal care and use in experimental research. The rat is the most widely used animal in studies on liver mitochondrial dysfunction, and therefore was used in this study. Male Wistar rats, weighing 250-300 g, were submitted to anesthesia with intraperitoneal diazepam + ketamine injection and divided into three groups: 1) control group (CTR) $(\mathrm{n}=12)$ subjected to simulated procedures only; 2) $1 d$ group, subjected to OJ for $24 \mathrm{~h}(\mathrm{n}=10)$; 3) $7 \mathrm{~d}$ group, subjected to OJ for $7 \mathrm{~d}(\mathrm{n}=10)$. The anterior abdomens of Group 1d and 7d animals were prepared for surgery by shaving and cleaning with iodopovidone.
Rats were then subjected to a median laparotomy, during which the common bile duct was identified, isolated, and then ligated at two adjacent points using a 4-0 cotton thread. The duct was then sectioned between the ligatures, in order to provoke OJ. The OJ animals were then maintained under observation in individual cages, given standard laboratory rat chow and water ad libitum for $24 \mathrm{~h}$ (group 1d) or $7 \mathrm{~d}$ (group 7d), at which time the animals were sacrificed by injection of an overdose of Sodium pentobarbitol. The rats livers were then immediately removed for analysis of hepatocyte mitochondrial function, and blood samples were collected for biochemical assessments (total bilirubin, AST, ALT, GGT, ALP). The animals of the CTR group were submitted to the same procedures as group $1 \mathrm{~d}$ and $7 \mathrm{~d}$ animals, except for the ligation and sectioning of the common bile duct. Dissected livers were immediately transferred to a Potter homogenizer, in a homogenizing solution (220 mM mannitol; $70 \mathrm{mM}$ sucrose; $5 \mathrm{~mL}$ MES pH 7.4; 2 mM EGTA and 0.2\% BSA) on ice, and homogenized. Lowry's method ${ }^{12}$ was used to determine protein content in the mitochondrial fraction. After centrifugation at $1,500 \times \mathrm{g}$ of the homogenate, the supernatant was centrifuged at $10,000 \mathrm{x} g$ in a centrifuge refrigerated to $0^{\circ} \mathrm{C}$, and the resulting pellet was suspended in a solution of the following composition: $220 \mathrm{mM}$ mannitol, $70 \mathrm{mM}$ sucrose, $5 \mathrm{mM}$ MOPS $\mathrm{pH}$ 7.4. Mitochondrial function was evaluated by polarography, using an $\mathrm{O}_{2}$ monitor (Yellow Spring Instr.) at $28^{\circ} \mathrm{C}$. The standard variables of mitochondrial respiration assessed were the ATP synthesis, the state 4 (S4) and state 3 (S3) of mitochondrial respiration, the S3/S4 respiratory control (RC) ratio, and the ADP to oxygen consumption (ADP/O) ratio. Incubation medium contained $80 \mathrm{mM} \mathrm{KCl,} 50 \mathrm{mM}$ MOPS pH 7.4, $4.5 \mathrm{mM}$ potassium phosphate, $0.1 \%$ BSA in a $2 \mathrm{~mL}$ total volume. Glutamate-malate was the substrate employed. Oxidative phosphorylation (S3) was started by addition of adenosine diphosphate (ADP, $280 \mathrm{nmol} / \mathrm{mL}$ ). S3 and $\mathrm{S} 4$ phases and respiratory control ratio $\mathrm{RC}=\mathrm{S} 3 / \mathrm{S} 4$, as well as the ADP consumption per consumed oxygen ratio $(\mathrm{ADP} / \mathrm{O})$ were determined. Total bilirubin and hepatic enzyme levels were measured by means of standard laboratory tests ${ }^{13}$

\section{Results}

As summarized in Table 1, there was a significant increase in $\mathrm{O}_{2}$ consumption during basal respiration (S4) in mitochondria preparations of the livers from OJ rats (ANOVA, $\mathrm{p}=0.009$ ). Following stimulation with ADP, the velocity of $\mathrm{O}_{2}$ consumption (S3) in OJ cells was not different from that of CTR cells (ANOVA, $\mathrm{p}=0.126$ ), but the RC value was significantly lower than that observed in the CTR group (ANOVA, $\mathrm{p} \leq 0.001$ ). 
TABLE 1 - Mitochondrial respiratory dysfunction in jaundiced rats hepatocytes

\begin{tabular}{llll}
\hline & CTR & 1d OJ & 7d OJ \\
\hline S3 & $197 \pm 9.1$ & $190 \pm 9.2$ & $161 \pm 10.4^{*}$ \\
S4 & $24 \pm 1.0$ & $28 \pm 0.9^{*}$ & $27 \pm 1.4^{*}$ \\
RC & $8.0 \pm 0.2$ & $6.6 \pm 0.1^{*}$ & $5.8 \pm 0.2^{*}$ \\
ADP/O & $2.7 \pm 0.2$ & $3.1 \pm 0.2$ & $2.2 \pm 0.1^{*}$ \\
\hline
\end{tabular}

S4: basal conditions; S3: in the presence of ADP; RC: respiratory control (S3/S4); ADP/O: ADP consumption/oxygen consumption rate. Data were determined for day 1 (ICT 24h), day 7 (ICT 7d), and control (CTR) group. ${ }^{*} \mathrm{p}<0.05$ for increase of S4; or decrease of S3, RC, and ADP/O, compared to corresponding CTR values.
The ADP/O ratio was not reduced in the $1 \mathrm{~d}$ group. All evaluated parameters of the respiratory chain (S3, S4, RC and ADP/O ratio) were significantly altered by $7 \mathrm{~d}$ after biliary occlusion. Total serum bilirubin concentration significantly increased in the first $24 \mathrm{~h}$ after biliary obstruction, relative to the CTR group, and was similar to that observed on the seventh day of biliary obstruction (Table 2). Furthermore, hepatic enzymes activity levels were significantly increased $24 \mathrm{~h}$ after induction of biliary obstruction relative to the CTR group (Table 2).

TABLE 2 - Disturbances induced by OJ on total bilirubin and enzymes activity

\begin{tabular}{llll}
\hline GROUPS & CTR & $1 \mathrm{~d}$ & $7 \mathrm{~d}$ \\
\hline Bilirubin (mg/dL) & $0.56 \pm 0.42$ & $4.2 \pm 1.7^{*}$ & $4.5 \pm 3.1^{*}$ \\
AST (TGO) (U/L) & $60.9 \pm 20.4$ & $557.3 \pm 153.1^{*}$ & $223.7 \pm 225.9^{*}$ \\
ALT (TGP) (U/L) & $43.0 \pm 11.8$ & $399.0 \pm 188.2^{*}$ & $87.1 \pm 51.7^{* * *}$ \\
GGT (U/L) & $2.1 \pm 1.7$ & $12.4 \pm 11.6^{* *}$ & $18.9 \pm 24.6$ \\
ALP (U/L) & $319.9 \pm 76.5$ & $1066.3 \pm 224.9^{*}$ & $696.0 \pm 159.4^{*}$ \\
\hline
\end{tabular}

Control group (CTR), Day 1 (ICT 24h - 1d) and Day 7 (ICT 7d). (ANOVA, $p<0.05$ ) * $\mathrm{p}<0.05$ ANOVA vs. CTR, ${ }^{* *} \mathrm{p}=0.084$ ANOVA vs. CTR, ${ }^{* * *} \mathrm{p}=0.082$ ANOVA vs CTR.

\section{Discussion}

Production of energy constitutes one of the main functions of the hepatocyte which, through the mitochondrial respiratory chain, performs oxidative phosphorylation and ATP synthesis. Reduction in this energy production is a basic component of the pathophysiology of severe OJ. ${ }^{10}$ In the present study, we found that total serum bilirubin and hepatic enzyme activity levels were elevated $24 \mathrm{~h}$ after biliary occlusion. This is 23 d earlier than observations reported previously. ${ }^{2,6,7,10,14}$ In basal conditions $\mathrm{S} 4$ represents the $\mathrm{O}_{2}$ consumption rate after ATP synthesis, and reflects the degree of coupling of mitochondrial respiration to ATP production. Meanwhile $\mathrm{S} 3$ represents the $\mathrm{O}_{2}$ consumption rate in the presence of ADP. Intact mitochondria in a milieu containing $\mathrm{NADH}$, $\mathrm{O}_{2}$ and $\mathrm{Pi}$, and a respiratory substrate (e.g. malate) will cease ATP synthesis as soon as endogenous ADP is exhausted. Addition of ADP rapidly restores the process, such that the S3 state is restored and ATP synthesis is resumed. Thus the S3/S4 ratio termed RC reflects the degree of coupling of mitochondrial respiration to ATP production. Meanwhile the ADP/O ratio indicates the amount of synthesized ATP per consumed oxygen ( $\mathrm{mol} \mathrm{ATP/mol} \mathrm{O}_{2}$ ) and can reveal $\mathrm{O}_{2}$ insufficiency in oxidative phosphorylation. ${ }^{2,15}$ We observed a significant increase in $\mathrm{O}_{2}$ consumption during basal respiration (S4) after $24 \mathrm{~h}$ of biliary occlusion. The observed decrement in the $\mathrm{RC}$ ratio indicates that although the rate of $\mathrm{O}_{2}$ consumption by mitochondria was maintained during stimulation with ADP (S3), the utilization of $\mathrm{O}_{2}$ for ATP generation was compromised in the cholestatic liver tissue of the 1d group. Although S3 depression has been reported in diverse studies of liver mitochondrial dysfunction in rats ${ }^{7}$ Nagano et al reported mitochondrial dysfunction from the $3^{\text {rd }}$ to the $21^{\text {st }}$ day of biliary obstruction evidenced by an S4 increase and an RC reduction, in the absence of an alteration in S3. ${ }^{6}$ Thus our 1d group findings here are consistent with Nagano et al's findings of increased S4 with an unchanged S3. In the present study, the alteration in mitochondrial function observed on the $1^{\text {st }}$ day of biliary obstruction became more marked on the $7^{\text {th }}$ day as evidenced by the persistence of RC and S4 alterations, and the addition of decreases in S3 and ADP/O ratio. Worsening of alterations in mitochondrial function with long-term biliary obstruction is commonly reported in the literature. ${ }^{6,7,9,16}$ Increased $\mathrm{O}_{2}$ consumption during S4 with decreased RC is indicative of respiratory chain depression, which ultimately leads to reduction in the production of high energy bonds (ATP). Our observation of increased S4 before an alteration in S3 could be observed seems to indicate a certain degree of uncoupling of the respiratory chain, potentially attributable to the presence of uncoupling agents. Uncoupling agents (e.g. 2,4-dinitrophenol) allow continuation of NADH oxidation and $\mathrm{O}_{2}$ reduction at high levels, but do not support ATP synthesis, thereby altering mitochondrial function. ${ }^{15,17}$ 


\section{Conclusion}

The results of this experimental study in rats show that $24 \mathrm{~h}$ after its induction, OJ provokes increased $\mathrm{O}_{2}$ consumption during the $\mathrm{S} 4$ phase of liver mitochondria respiration, as well as decreased RC, indicative of respiratory chain depression. This early respiratory chain depression may lead to early reduction in the production of high energy bonds (ATP) by liver mitochondria. This early alteration in liver mitochondrial function was concomitant with increased serum bilirubin levels and increased hepatic enzyme activity levels.

\section{References}

1. Mori K, Ozawa K, Yamamoto Y, Maki A, Shimahara Y, Kobayashi N, Yamaoka Y, Kumada K. Response of hepatic mitochondria redox state to oral glucose load. Ann Surg. 1990;211:438-46.

2. Chang Y-J, Iwata S, Terada Y, Ozawa K. Restricted redox oscillation in Oxidative phosphorylation in jaundiced rat liver mitochondria and its relation to calcium ion. J Surg Res. 1996;66:91-9.

3. Mustafá MG, Cowger ML, and King TE. Efects of bilirubin on mitochondrial reactions. J Biol Chem. 1969;244:6403-14.

4. Suzuki K, Koyama K, Asanuma Y, Ouchi S, Tanaka J, Shirayama K, Yoshida S. Respiratory function of mitochondria fractionated from isolated hepatocytes of rats with obstructive jaundice. Nippon Geka Gakkai Zasshi. 1988;89:703-8.

5. Kato S, Nagano I, Nimura Y, Wokabayashi T. Hepatic recovery after biliary drainage in experimental obstructive jaundice complicated by biliary infection. Hepato-Gastroenterol. 1994;41:217-21.

6. Nagano I, Kato, S, Nimura Y, Wakabayashi T. Hepatic mitochondrial changes in experimental obstructive jaundice complicated by biliary infection. HepatoGastroenterol. 1994;41:432-7.

7. Nishimura D, Imoto M, Satake T, Sugiyama S, Ozawa T. Mechanism of liver mitochondrial dysfunction associated with bile duct obstruction. Arzneimittelforschung. 1985;35:1427-30.

8. Isaksson B, Rippe C, Simonoska R, Holm JE, Glaumann H, Segersvard R, Larsson J, ErlansonAlbertsson C, Permert J. Obstructive jaundice results in increased liver expression of uncoupling protein 2 and intact skeletal muscle glucose metabolism in the rat. Scand J Gastroenterol. 2002;37:104-11.

9. Koyama K, Ito K, Ouchi K, Sato T. Mitochondrial function of rat liver in biliary obstruction.Tohoku J Exp Med. 1980;131:59-69.

10. Asanuma Y, Koyama K. Effect of nonbioogical hepatic assist on the mitochondrial function of the liver: basic considerations. Artif Organs. 1994;18:367-70.

11. Kanai M, Tanaka M, Nimura Y, Nagino M, Katoh T, Ozawa T. Mechanism of adaptive increase of respiratory enzymes in rat liver mitochondria during obstructive jaundice. Japan Biochem Int. 1991;23:1165-73.

12. Lowry OH, Rosebrough NJ, Farr AL, Randall RJ. Protein measurement with the Folin phenol reagent. J Biol Chemistry. 1951;193:265-75.

13. Burtis CA, Ashwood ER. Tietz textbook of clinical chemistry. Philadelphia: W. B. Saunders Co; 1999.

14. Fraser IA, Shaffer P, Tuttle SV, Lessler MA, Ellison EC, Carey LC. Hepatic recovery after biliary decompression of experimental obstructive jaundice. Am J Surg. 1989;158:423-7.

15. Darnell J, Lodish H, Baltimore D. Molecular cell biology. New York: Scientific American Books; 1990.

16. Clemens WDB, Diamond T, McLrory, Rowlands BJ. Biliary drainage in obstructive jaundice: experimental and clinical aspects. Br J Surg. 1993;8:834-42.

17. Coelho AMM, Machado MCC, Sampietre SN, Leite KRM, Molan NAT, Pinotti HW. Lesão hepática na pancreatite aguda experimental: influência da redução da reserva enzimática do pâncreas. Rev Hosp Clin Fac Med USP. 1998;53:104-9.

\section{Correspondence:}

Belchor Fontes

Rua Itacema, 246/11

04530-050 São Paulo - SP Brazil

Phone: (55 11)8109-0033 / 3079-3048

belchor@uol.com.br
Conflict of interest: none Financial source: none

Received: March 19, 2007 Review: May 15, 2007 Accepted: June 15, 2007

\section{How to cite this article}

Younes RN, Poggetti RS, Fontes B, Itinoshe MM, Yoshida VM, Carvalho MEA, Birolini D. Obstructive jaundice induces early depression of mitochondrial respiration in rat hepatocytes. Acta Cir Bras. [serial on the Internet] 2007 July-Aug;22(4). Available from URL: http://www.scielo.br/acb 